\title{
Coronavirus in the Children's World: Discourses and Drawings
}

\author{
Nil Duban \\ Afyon Kocatepe University, Education Faculty, Afyonkarahisar, TURKEY \\ Fatma Gül Şen \\ Istek Primary School, Kütahya, TURKEY
}

Received: 26 March 2021 • Accepted: 4 July 2021 • Published Online: 23 August 2021

\begin{abstract}
More than 1.5 billion students and young people worldwide have been affected by school and university closings due to the COVID-19 outbreak. With the closure of schools due to the COVID19 pandemic in Turkey, a free distance education system was launched by the Ministry of Education on 23 March 2020 with a national level television and internet-based curriculum. The opinions of the children who have just started primary school but whose school has been closed due to the pandemic in the spring term are considered to be necessary. The aim of this study was to determine the perspectives of $1^{\text {st }}$ grade primary school (6.5-7 years old) students on the Coronavirus and its effects. In current study, the perspectives of $1^{\text {st }}$ grade primary school students on Coronavirus and its effects were investigated. In this context, interview and document analysis techniques were used within the scope of qualitative research methods. A total of 16 primary school students from four provinces in different geographical regions of Turkey were included in the study to ensure maximum diversity. These students formed the working group of the research. In the study, semi-structured interviews and pictures drawn by students were used to reveal students' perspectives on Coronavirus and the effects of the virus. In the research, semistructured interviews were used for content analysis, and the pictures drawn were utilized for document analysis. In the study, it was assumed that $1^{\text {st }}$ grade primary school students have the consciousness that Coronavirus has tremendous and adverse effects on human life and threatens health. it was concluded that 1st grade primary school students gained awareness about proper handwashing, using masks and gloves as a means of protection from Coronavirus.
\end{abstract}

Keywords: Coronavirus, COVID-19 pandemic, children, primary school students.

\section{Introduction}

The number of patients admitted to the hospital with viral pneumonia in China in December 2019 showed that this was due to the new Coronavirus disease (COVID-19). The COVID-19 outbreak turned into a pandemic very quickly (Yıldız et al., 2020). On 30 January 2020, the WHO announced that an international worrying public health emergency would break out due to COVID-19. And in March 2020, the WHO began to describe it as a pandemic to emphasize the seriousness of the situation and encourage all countries to take action (Güner et al. 2020).

(C) Authors. Terms and conditions of Creative Commons Attribution 4.0 International (CC BY 4.0) apply. Correspondence: Nil Duban, Afyon Kocatepe University, Education Faculty, Afyonkarahisar, TURKEY. E-mail: nily@aku.edu.tr. 
On 11 February 2020, WHO called the new Coronavirus-induced pneumonia Coronavirus Disease 2019 (COVID-19). Symptomatic transmission refers to transmission from a person with symptoms. It is the primary mode of transmission, and breathing droplets occur either through direct contact with infected people or through contact with contaminated objects and surfaces (Malik, 2020). After touching the surfaces contaminated with the respiratory particles of the patients, the virus can be removed by taking the hands to the face, eyes, nose, or mouth without washing. It is risky to touch the eyes, nose, or mouth with dirty hands (Ministry of Health, 2020).

The current global epidemic, which caused a large number of deaths due to COVID-19 infection, is spreading rapidly in many countries. The available information on COVID-19 is limited, but it is quickly evolving. During this outbreak, the medical community uses data collected from past SARS-CoV and MERS-CoV outbreaks to predicting the behavior, clinical presentation, and treatment of COVID-19. Many countries only apply restrictions that allow significant activities, and health systems around the world are trying to manage the increase in critical patient influx (Gulati et al., 2020).

Having knowledge and facts about COVID-19 will help reduce students' fears and concerns about the disease and support their ability to cope with secondary effects in their lives. For this, it is essential to listen to children's interests and answer their questions in an ageappropriate manner, and they should not be overwhelmed with much information. It is recommended to encourage children to express their feelings and to discuss the different reactions they may face and explain that these are normal reactions to an abnormal situation (UNICEF, 2020). Similarly, in the study conducted by Gray et al. (2020), the necessity of video / cartoonbased entertainment-education intervention was revealed for children by mentioning the importance of strengthening and habituation of correct hygiene practices.

The main factor of slowing down the outbreak or stopping the virus is classical approaches, which include social withdrawal, quarantine, and mobility interventions as there is currently no treatment (Lee Minha, 2020). In addition to the necessary medical care in the current outbreak, all individuals around the world need to be aware of the security measures to be followed during the pandemic (Venigalla \& Dheeraj, 2020). First of all, the World Health Organization (WHO, 2020) listed the items related to protecting ourselves and others from the COVID-19 outbreak as follows:

- Clean your hands regularly by rubbing them with an alcoholic base or wash them with soap and water.

- Keep at least one-meter distance between you and others.

- Avoid going to crowded places.

- Avoid touching the eyes, nose, and mouth.

- If you need to leave your home, wear a mask to prevent contamination with others.

- Get medical attention if you have a fever, cough, and trouble breathing.

- Track the latest information from reliable sources such as WHO or local and national health authorities.

Covid-19 may be transmitted as an aerosol infection, to cope with possible similar infections in the future, we have to wear masks in highly polluted areas and care for hand hygiene to prevent direct transmission of infections from contaminated surfaces. However, some precautionary measures should be taken, such as not smoking and maintaining social distancing with symptomatic individuals both at home and at work (Shoor et al., 2020).

Social distancing is particularly useful for preventing the further transfer to people who are believed to have a community transfer but the connections between cases are uncertain 
and only known to be exposed. Social distancing includes examples, such as the closure of schools or office buildings, cancellation of public meetings (Wilder-Smith \& Freedman, 2020). Social distancing is a realistic solution that all individuals can participate in to reduce the risk of infection while increasing available resources for critical patients during this pandemic (Sen-Crowe, McKenney \& Elkbuli, 2020). To alleviate the epidemic of COVID-19, one of the critical (nonpharmacological) control measures in reducing the transmission rate of SARS-COV-2 in the population is the social (physical) distance (Gao et al., 2020).

Individual measures to avoid Covid-19 include working remotely, avoiding public transport, and staying at home. Among social criteria, the transition to online education is the widespread engagement of telecommunication (Sen-Crowe, McKenney \& Elkbuli, 2020).

In addition to the measures, we can take individually in the event of an outbreak, governments issue "stay at home" orders to reduce the spread of infectious diseases. The COVID19 epidemic also led to the widespread implementation of extraordinary physical distance interventions (for example, home orders) to slow the spread of the virus (Fowler et al., 2020; Tull et al., 2020).

Following the exponential growth in the number of approved cases, the Federal Emergency Management Agency (FEMA) announced its first major disaster in the state of New York on 20 March 2020, followed by California and Washington on 22 March (FEMA, 2020). As of 11 April 2020, FEMA declared the COVID-19 pandemic disaster in each state, and Wyoming became the last. On 19 March 2020, California became the first state to order "Stay at Home" (Chenfeng Xiong et al. 2020).

The Turkish government has also implemented various protection measures. These include social distance, travel restrictions from visitors from high-risk areas, and quarantine measures for citizens returning from high-risk places. The closure of schools and specific workplaces are among the actions taken. In Turkey, the government closed all its schools, including universities, as of 16 March (Güner et al. 2020). Turkey has been utilized in distance education with the closure of schools due to the pandemic. With a network called EBA (Education Information Network), necessary compensation training support has started to be provided over the internet and television screens. Primary, secondary, and high school level courses have been carried out by distance education.

Despite the nature of the process, when the literature is analyzed, although there are many studies on Coronavirus and COVID-19 in medicine, researches in educational sciences and social sciences are almost nonexistent. To fill this gap in the literature and to reveal the effects of the process, searches should be done in all branches of science. The group that needs to be provided with psychological support and increased psychological resilience primarily in the COVID-19 process is children (Çaykuş \& Mutlu Çaykuş, 2020). UNESCO and teachers also support this situation, and school administrators are encouraged to teach life by using educational applications to help communicate with children in almost all countries (Chang and Satoko Yano, 2020). In this context, the opinions of the children who have just started primary school but whose school has been closed due to the pandemic in the spring term are considered to be necessary. The aim of this study was to determine the perspectives of $1^{\text {st }}$ grade primary school (6.5-7 years old) students on the Coronavirus and its effects. For this purpose, answers were sought for the following questions:

(1) How do $1^{\text {st }}$ grade primary school students define Coronavirus?

(2) What information do $1^{\text {st }}$ grade primary school students have on Coronavirus?

(3) What are the thoughts of $1^{\text {st }}$ grade primary school students regarding the effects of Coronavirus? 
(4) What comes to life in the Coronavirus minds of $1^{\text {st }}$ grade primary school students?

\section{Method}

The qualitative research method is a method that uses an inductive approach where the researcher is allowed to get out of the data of the analysis categories as the study progresses and starts with specific observations (Mertens, 2010). Qualitative research methods are used in study designed to provide an in-depth description of a particular program, application, or environment. In current study, the perspectives of $1^{\text {st }}$ grade primary school students on Coronavirus and its effects were investigated. In this context, interview and document analysis techniques were used within the scope of qualitative research methods.

\subsection{Participants}

In the research, maximum diversity sampling, which is one of the purposeful sampling types, was used to determine the participants. Maximum diversity sampling is a sampling type that covers both outlier and typical cases (Palys, 2008). A total of 16 primary school students from four provinces in different geographical regions of Turkey were included in the study to ensure maximum diversity. These students formed the working group of the research.

\begin{tabular}{|c|c|c|c|c|c|c|}
\hline Participant & Gender & $\begin{array}{l}\text { School } \\
\text { type }\end{array}$ & $\begin{array}{l}\text { Mother's } \\
\text { Educational } \\
\text { Status }\end{array}$ & $\begin{array}{l}\text { Father's } \\
\text { Educational } \\
\text { Status }\end{array}$ & $\begin{array}{l}\text { Number } \\
\text { of } \\
\text { children }\end{array}$ & Region \\
\hline Ali Kerem & Male & $\begin{array}{l}\text { State } \\
\text { school }\end{array}$ & Undergraduate & Undergraduate & 3 & $\begin{array}{l}\text { Southeastern } \\
\text { Anatolia }\end{array}$ \\
\hline Azra & Female & $\begin{array}{l}\text { State } \\
\text { school }\end{array}$ & Primary school & High School & 2 & $\begin{array}{l}\text { Southeastern } \\
\text { Anatolia }\end{array}$ \\
\hline Beren & Female & $\begin{array}{l}\text { State } \\
\text { school }\end{array}$ & Primary school & Associate degree & 4 & $\begin{array}{l}\text { Southeastern } \\
\text { Anatolia }\end{array}$ \\
\hline Hamza & Male & $\begin{array}{l}\text { State } \\
\text { school }\end{array}$ & Primary school & High School & 3 & $\begin{array}{l}\text { Southeastern } \\
\text { Anatolia }\end{array}$ \\
\hline Muhammed Ali & Male & $\begin{array}{l}\text { State } \\
\text { school }\end{array}$ & Secondary School & High School & 4 & East Anatolia \\
\hline Leya & Female & $\begin{array}{l}\text { State } \\
\text { school }\end{array}$ & High School & High School & 4 & East Anatolia \\
\hline Irmak & Female & $\begin{array}{l}\text { State } \\
\text { school }\end{array}$ & High School & High School & 5 & East Anatolia \\
\hline Berra & Female & $\begin{array}{l}\text { State } \\
\text { school }\end{array}$ & Secondary School & High School & 4 & East Anatolia \\
\hline Muhammed & Male & $\begin{array}{l}\text { State } \\
\text { school }\end{array}$ & Secondary School & Secondary School & 3 & Central Anatolia \\
\hline Alperen & Male & $\begin{array}{l}\text { State } \\
\text { school }\end{array}$ & Primary school & Primary school & 3 & Central Anatolia \\
\hline Rabia & Male & $\begin{array}{l}\text { State } \\
\text { school }\end{array}$ & Secondary School & High School & 2 & Central Anatolia \\
\hline Hazal Melek & Female & $\begin{array}{l}\text { State } \\
\text { school }\end{array}$ & High School & High School & 2 & Central Anatolia \\
\hline Mehmet Taha & Male & $\begin{array}{l}\text { Private } \\
\text { school }\end{array}$ & Undergraduate & Undergraduate & 2 & Aegean \\
\hline Mehmet Akif & Male & $\begin{array}{l}\text { Private } \\
\text { school }\end{array}$ & Undergraduate & Undergraduate & 2 & Aegean \\
\hline Ayşe & Female & $\begin{array}{l}\text { Private } \\
\text { school }\end{array}$ & Undergraduate & Undergraduate & 2 & Aegean \\
\hline Aybike & Female & $\begin{array}{l}\text { Private } \\
\text { school }\end{array}$ & Undergraduate & Undergraduate & 1 & Aegean \\
\hline
\end{tabular}




\subsection{Data collection}

In the study, semi-structured interviews and pictures drawn by students were used to reveal students' perspectives on Coronavirus and the effects of the virus. Researchers prefer to interview when they want to understand the aspects of the participants or learn how the participants give meanings to facts and events (Berg \& Lune, 2015: 139). In this study, one of the interview techniques, semi-structured interview, was used. The semi-structured interview is a qualitative data collection strategy, where the researcher asks participants a set of predetermined but open-ended questions (Ayres, 2008). In this study, first, semi-structured interview forms containing questions about Coronavirus were sent to the parents of the students via WhatsApp application. Parents were asked to see if they found it appropriate for their children to answer these questions. After the "I have no objection in my child to answer these questions," permission from the families, interviews were performed with the students. The conversations were recorded.

Documents were written or printed materials prepared in the form of annual reports, artwork, books, cartoons, diaries, diplomas, newspapers, magazines, notebooks, school yearbooks, memories, tests, etc. These documents could be manuscripts, printed, typed, drawn (pictures), drafted, or unpublished (Fraenkel, Wallen \& Hyun, 2012). As part of this study, pictures drawn by students were used as documents. Instead of relying only on verbal descriptions, researchers can ask interviewed people to draw their perceptions, feelings, and situations. The comments drawn from the drawings will certainly support strengthening the study results (Arthur, Waring, Coe \& Hedges, 2012). Within the scope of this research, to provide triangulation, and to make the study more reliable, the participant students were asked to paint on the "Coronavirus." After the pictures of the students were analyzed, they were used together with their opinions to support each other.

\subsection{Validity and reliability}

In qualitative research, for internal validity or credibility, expert review is one of the strategies used (Merriam, 2013). As a data collection tool, a semi-structured interview form containing six open-ended questions was prepared by the researchers. To ensure credibility in the research, a form was presented to two academicians who are experts in primary school education and qualitative research. After the examinations made by the experts, the form was rearranged according to their opinions and suggestions, and the total number of questions was determined as four.

In qualitative research, the reliability data set means stability in the responses of more than one encoder. Regarding reliability, intercoder consensus can be used based on the use of multiple encoders for analysis of transmitted data (Creswell, 2015). In this study, by comparing the codes created by the researchers independently from each other, points with consensus and disagreement were determined. For the reliability calculation, the reliability formula (Reliability=Consensus/(Consensus+Disagreement)) proposed by Miles and Huberman (1994) was used. The reliability of the study was calculated as 90 at the end of the calculation.

\subsection{Data analysis}

In the research, semi-structured interviews were used for content analysis, and the pictures drawn were utilized for document analysis.

Content analysis is the process of separating qualitative data into similar themes or sets of conceptual categories to identify consistent patterns and relationships between variables (Julien, 2008). The primary purpose of content analysis is to reach concepts and connections that can explain the collected data. The necessary process in content analysis is to gather the data 
similar to each other within the framework of specific concepts and themes and to arrange them in a way that the reader can understand (Ylldırım \& Şimşek, 2013: 259). In this research, each participant's answers were analyzed in small paragraphs and labeled by writing codes next to each paragraph. After the tagging operation, which categories the codes issued will be used is defined. The obtained categories were grouped in such a way to form meaningful whole, and sub-themes were developed. In this manner, sub-themes and categories to be included under the key theme were prepared and shown on the table. Next, each of them was explained in detail as the study findings.

In document analysis, documents are seen as communication channels containing meaningful messages between the author and the reader (Prior, 2008). The first step, while using the materials as a data source in qualitative research, must be finding the necessary and useful documents. Afterward, the originality of the documents should be checked. When these conditions are met, the researcher should establish a system for coding and cataloging and finally interpret the documents by analyzing them (Merriam, 2013: 142-143). In this study, children's picture's originality was observed by examining whether they are related to the Coronavirus. These pictures were numbered and classified according to their subject (those with virus form, those with hygiene, those with social distance emphasis, etc.). Then, the researchers analyzed the pictures one by one, and the codes for each picture were created. The codes obtained from the analysis of the pictures were matched with the categories that emerged in the analysis of the interviews to assure triangulation. In the presentation of the findings, direct quotations from the participants' views and examples from the pictures they have drawn are given.

3. Results

\begin{tabular}{|c|c|c|}
\hline Theme & Sub-theme & Category \\
\hline \multirow{4}{*}{ Coronavirus } & What? & $\begin{array}{l}\text { Disease } \\
\text { Epidemic }\end{array}$ \\
\hline & What are the features? & $\begin{array}{l}\text { It is contagious } \\
\text { It is dangerous } \\
\text { It is fatal }\end{array}$ \\
\hline & How is it protected? & $\begin{array}{l}\text { Hands are washed } \\
\text { Mask and gloves are worn } \\
\text { Stay home } \\
\text { Social distance is maintained } \\
\text { Attention to cleanliness } \\
\text { Mouth, nose, and eyes are not touched } \\
\text { with hands }\end{array}$ \\
\hline & What are the effects of life? & $\begin{array}{l}\text { Caused schools to close } \\
\text { Caused distance education }\end{array}$ \\
\hline
\end{tabular}

\subsection{Results on the sub-theme: "What is Coronavirus?"}

The children tried to identify the Coronavirus in many ways and ultimately reached the same common point. Under the "What is Coronavirus" sub-theme, disease and epidemic categories have emerged.

\subsubsection{Disease}

a disease."

Hayri described the Coronavirus as a disease: "The Coronavirus is a microbe, so it is 
Similarly, Azra said: "Coronavirus is a disease. It is a disease that will give us the flu." seen.”

Hazal Melek explained the Coronavirus as a disease: "A different disease we have not

\subsubsection{Pandemic}

Beren described the Coronavirus as a pandemic: "I know it is a dangerous pandemic when we go out." world."

Ali Kerem expressed the virus with the words "a pandemic spreading all over the

Leya also described the Coronavirus as "a pandemic that is transmitted to all and is seen worldwide."
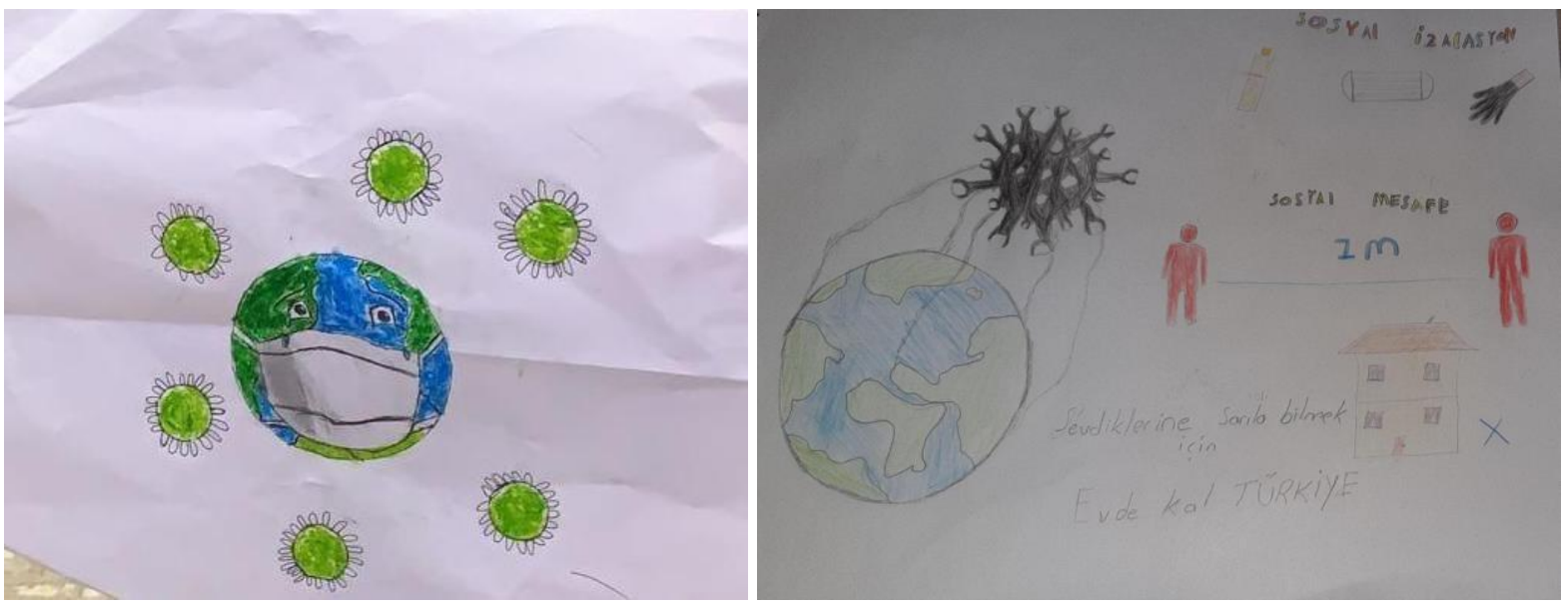

The children tried to emphasize that they perceive Covid-19 as a pandemic in the pictures they draw by drawing a world that this epidemic is global. It is noteworthy that in the first picture, many viruses are enclosing the world, and picture on the right, a giant virus surrounds the world with its networks.

It has been shown that the children possess a general awareness of the Coronavirus from their narratives and pictures. Children cannot technically express that the Coronavirus turns into a pandemic called Covid-19. Still, they stated that it is a worldwide epidemic and that Coronavirus is a kind of disease that damages people's health.

\subsection{Results on the sub-theme: "What are the features of Coronavirus?"}

Children described the characteristics of Coronavirus. In this context, the categories of infectious, dangerous and deadly emerged under the sub-theme of "What are the properties of Coronavirus."

\subsubsection{Contagious}

Regarding that, the Coronavirus is contagious, Muhammed used the following statement: "Coronavirus can be transmitted through our mouth, through our nose, and our eyes." 
Ali Kerem stated that Coronavirus is contagious as follows: "A killer virus. So it is transmitted from person to person, for example."

Likewise, Aybike has described it as "lethal, contagious, and has spread properties."

As for Ayşe, she commented about the Coronavirus being contagious: "It is a highly infectious disease. It can make you very ill."

\subsubsection{Dangerous}

Stating that the Coronavirus is dangerous, Beren used the following statement: "I know that there is a danger when we kiss, shake hands, and go outside."

On the other hand, Mehmet Akif described the Coronavirus as dangerous: "I know it is deadly, dangerous, living in the water and contagious."

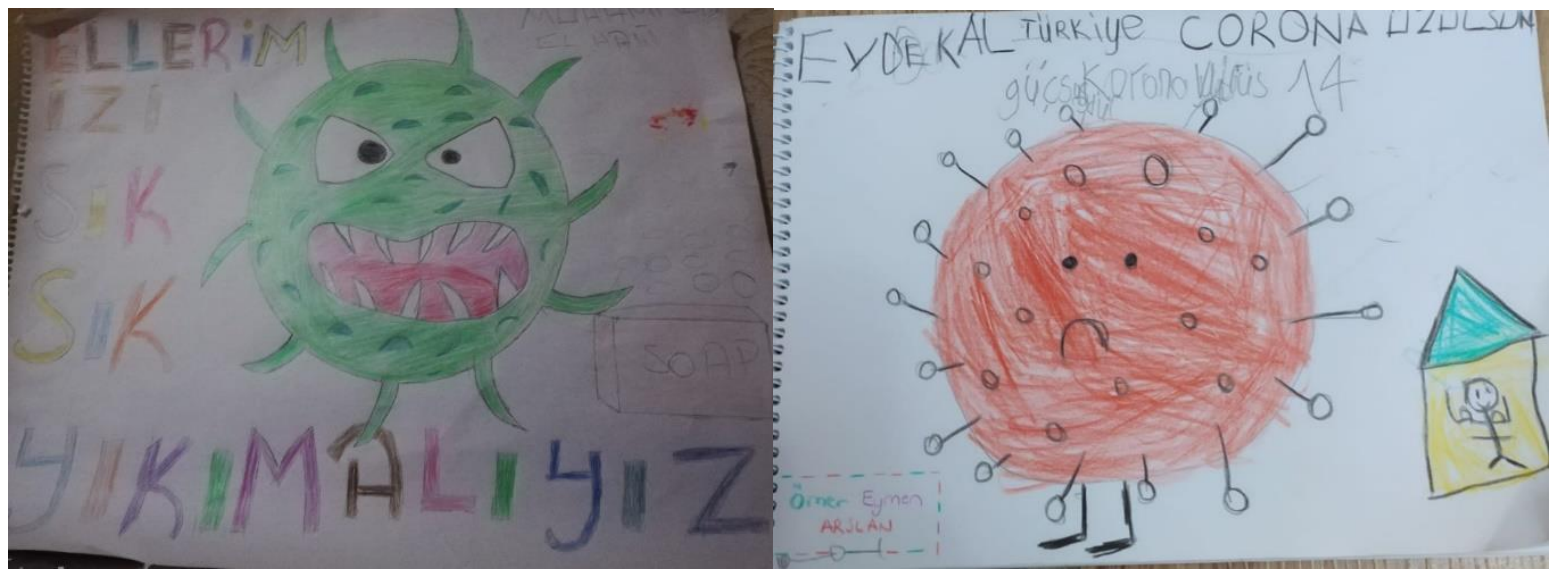

Children drew the Coronavirus in the microscopic form they see on the screen. The picture on the left is drawn with sharp teeth, with a spooky facial expression, and the picture on the right is a giant virus with a sad face.

\subsubsection{Fatal}

Ali Kerem stated that Coronavirus is fatal as follows: "One killing virus. In other words, it is transmitted from person to person." properties."

Aybike also described the Coronavirus as fatal as "lethal, contagious, and has spread

Rabia used the following statement that the Coronavirus is fatal: "I know some people are dead and some are defeating the Coronavirus."

According to the children's statements, it can be mentioned that they are aware of how effective Coronavirus is on human life and threatens health. This consciousness directs them to be more cautious about taking precautions against Coronavirus. Their emphasis on Coronavirus prevention in their later narratives and drawings indicate that children are aware of the adverse effects of Coronavirus. 
3.3 Results on the sub-theme: "How to protect from the Coronavirus?"

Children addressed the importance of hygiene to prevent Coronavirus and the precautions to be taken at this point. In this context, the categories of washing hands, wearing masks and gloves, staying at home, maintaining social distance, paying attention to cleanliness have emerged under the sub-theme of "How to protect corona from the virus."

\subsubsection{Washing hands}

Alperen said that we should wash our hands to protect against Coronavirus and said: "We should wash our hands with soap and water for 20 seconds."

Likewise, Azra replied: "I wash my hands with soap for 20 seconds."

Leya stated that we must wash our hands to protect against Coronavirus: "When we come from outside and come out of the toilet, we wash our hands by counting down from 20."

Aybike also stated her view on Coronavirus protection as: "We should wash our hands frequently with soap and water for at least 20 seconds."

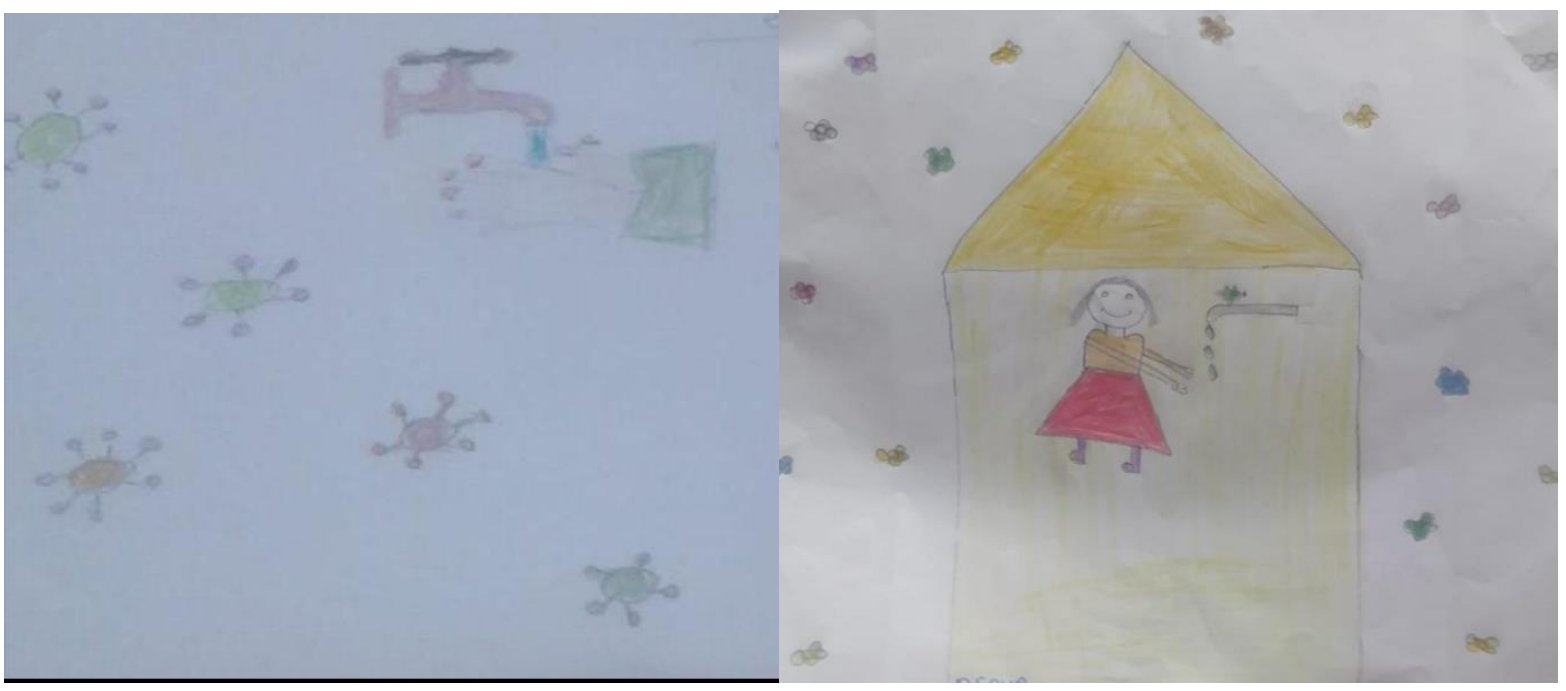

As they described in the interviews, children tried to emphasize that hand hygiene is essential and that they should wash hands in different ways in their drawings. In the picture on the right, the hygiene importance is tried to be explained with a large hand-drawn under a waterflowing tap, the house, and slogans protecting from the virus in the environment.

\subsubsection{Wearing a mask and gloves}

Ayşe stated that a mask should be worn to protect against Coronavirus and said: "We should use a mask when we have to go out."

Similarly, Aybike used the expression: "We should wear a mask when we go out" to protect against Coronavirus.

Rabia stated that she wears a mask and gloves to protect against Coronavirus: "We wear masks and gloves to protect them."

Similarly, Hamza stated his method of protection by saying: "We must wear gloves and a mask to protect against Coronavirus." 


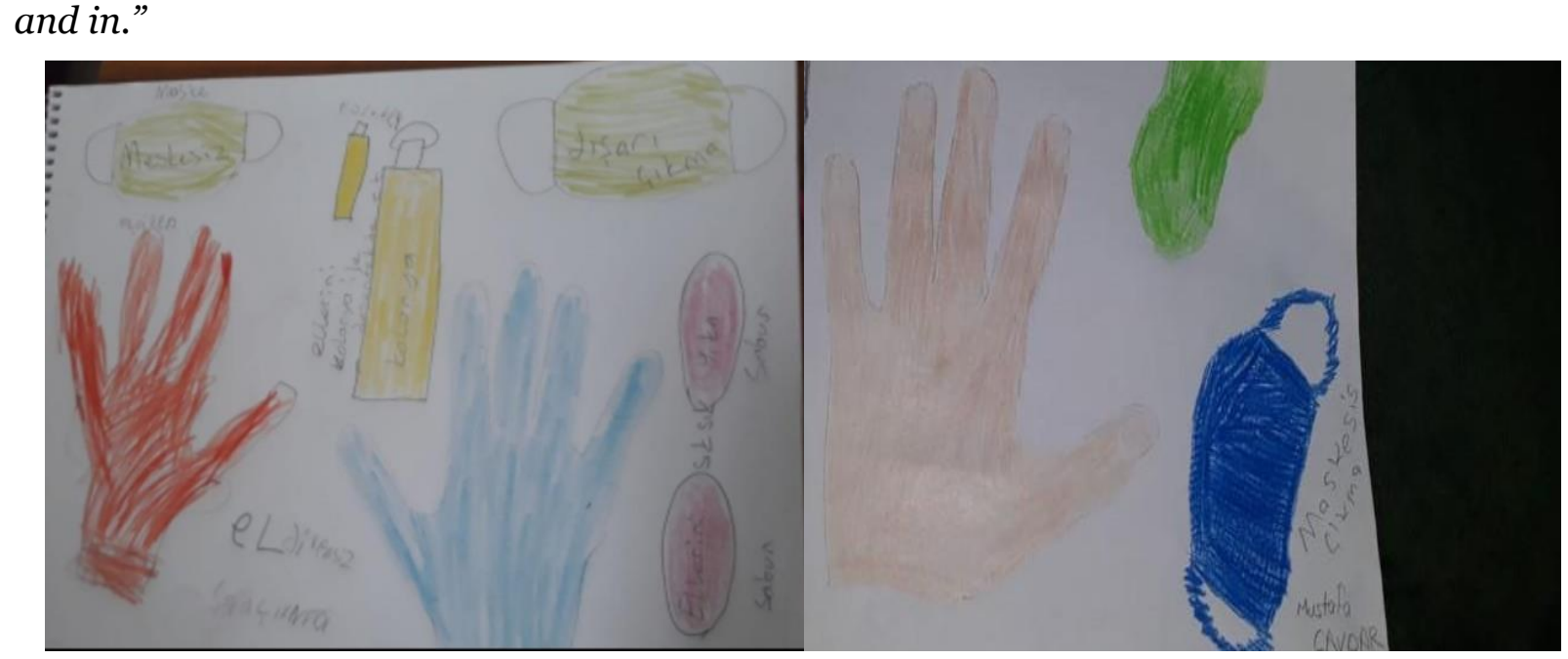

By expressing the importance of using masks and gloves, the children tried to emphasize the ways of virus protection by drawing masks, gloves, disinfectants, and cologne in the pictures they draw. In the picture on the left, two hands wearing gloves of different colors, two mask-sized, and small bottles of cologne were tried to emphasize the importance of masks and gloves. In the picture on the right, the hands, and the importance of the mask are emphasized.

\subsubsection{Staying at home}

Ayşe answered the "How should we protect from Coronavirus?" by saying: "We should not go out. We should also use a mask when we have to go out." at home."

Mehmet Taha also expressed his opinion and said: "We shouldn't go out. We must stay

Stating that staying at home will provide virus protection, Alperen said: "We remain at home protected from the virus and not to be sick."

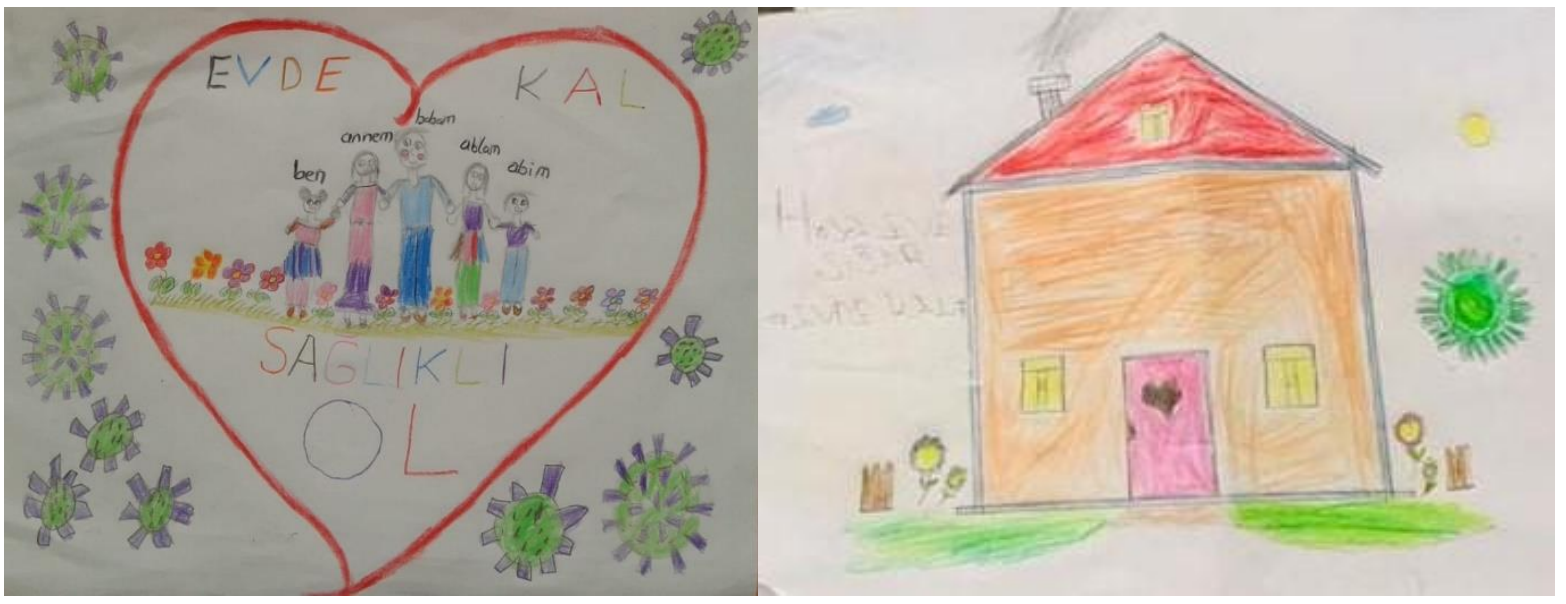

The children believed that staying at home is essential for protection from the virus and stated in their drawings that the houses are a loving place, isolated from Coronavirus.

Azra stated that she was staying at home because of the virus and expressed her feeling as follows: "I am staying at home because there is a virus." 

infect us.”

Hamza, on the other hand, said: "I stay at home so that the Coronavirus does not

Beren expressed his view that the virus caused the stay: "They say stay home because there is a Coronavirus."

Stating that staying at home is a way of protection, Mehmet Taha used the following statement: "There is a Coronavirus, let's don't go out and be protected."

Rabia also said: "We should stay at home so that Coronavirus does not come to us," and said that the reason for staying at home is for protection.

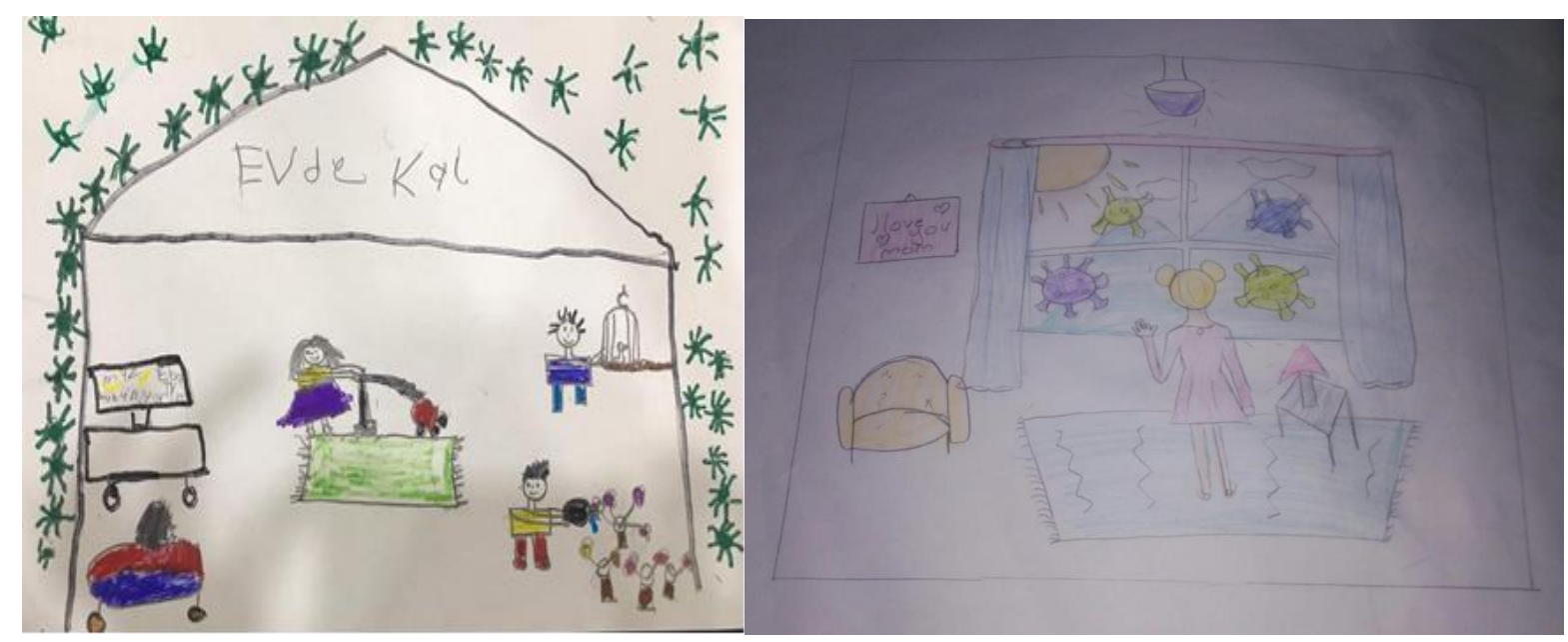

In their discourses, the children stated that they perceived the Coronavirus as a factor that caused their stay at home. Similarly, they drew pictures describing that life in the house is protected. In the picture on the left, the viruses that do not enter, although they surround the house, are highlighted. In the picture on the right, it is tried to be expressed that the viruses are outside the window, cannot enter. Thus, the interior of the house is healthy.

\subsubsection{Maintaining social distance}

Muhammed drew attention to the importance of social distance to protect from Coronavirus and used the expression: "We must put two steps away."

Mehmet Akif made a similar statement saying: "We must stay one meter away."

Ali Kerem talked about the social distance to protect against Coronavirus, and gave an opinion as follows: "We should not be in contact with people."

On the other hand, Irmak stated the social distance rule to be protected from Coronavirus by using the following expressions: "We should not go to crowded places." environment."

Similarly, Hazal Melek used the phrase: "We should not be in a collective 

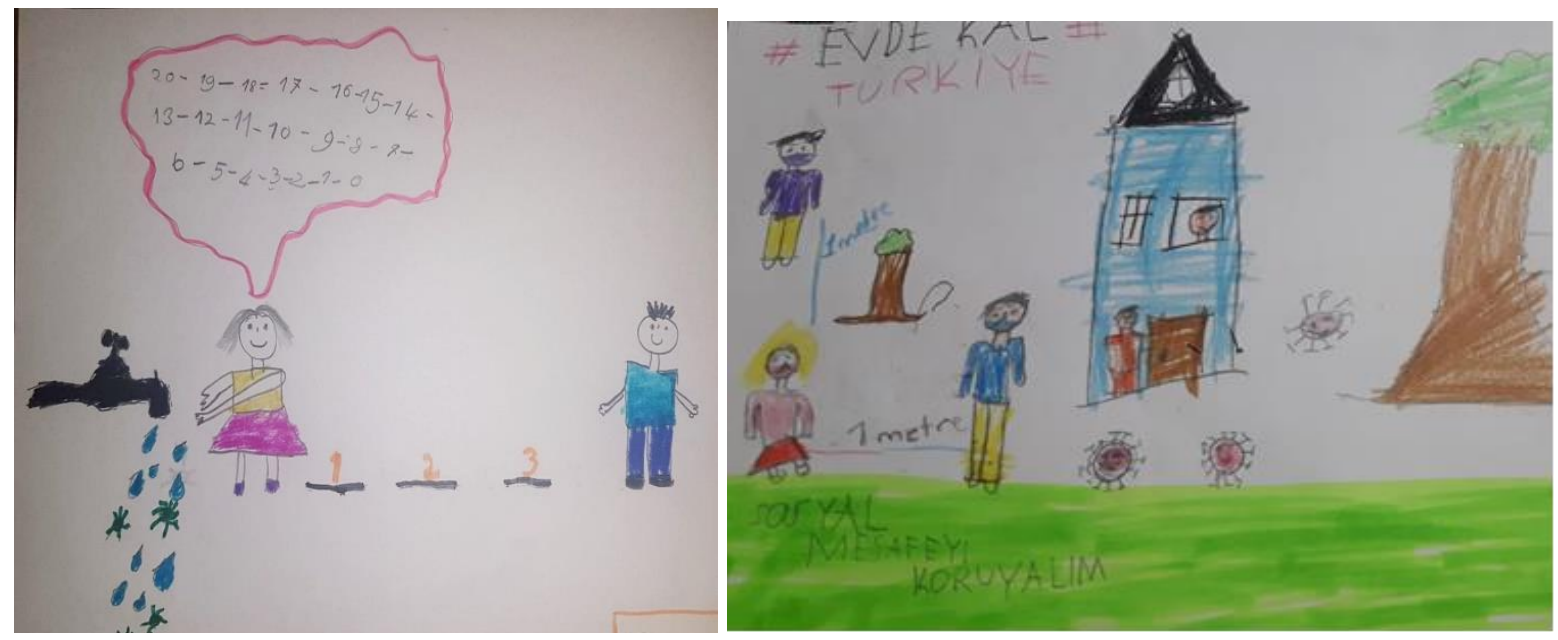

The children exhibited the principle of preserving the social distance expressed in their conversations also in their paintings. The drawing of the child, who washes hands for 20 seconds by counting down from 20 in the picture on the left and emphasizes three steps to protect the social distance with his friend, draws attention. In the picture on the right, one-meter distance is drawn between people with masks on their faces.

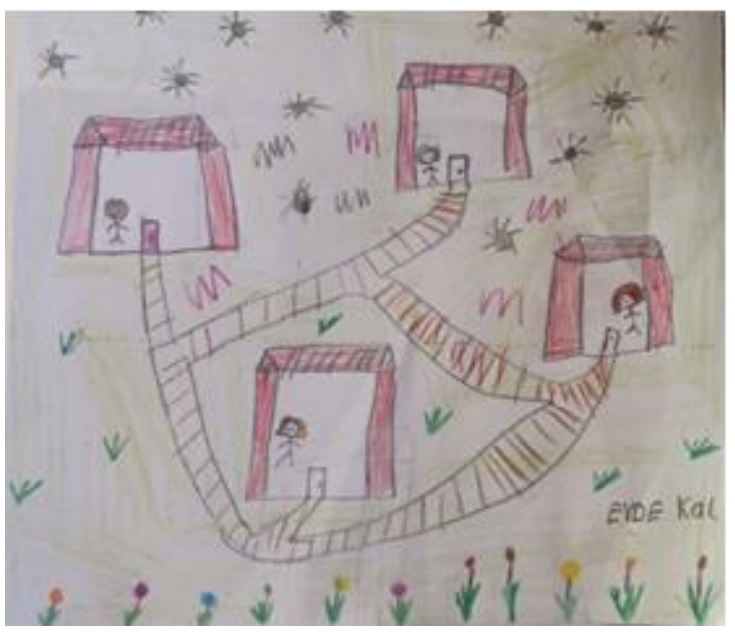

In children's other pictures, the drawings that stand out the importance of social isolation are the people who live in their homes without isolating themselves in the neighboring houses with distance and without getting into the crowd.

\subsubsection{Attention to cleanliness}

Aybike talked about Coronavirus protection and clothing cleaning with the words: "We should wash our clothes with normal detergent between 60 and 90 degrees. We should clean the surfaces we frequently use every day."

Ali Kerem expressed his view on Coronavirus protection by saying: "We should not take our hands to our mouth, nose, and eyes."

Muhammed Ali similarly expressed his opinion by saying: "We will not touch our face with our hands.” 

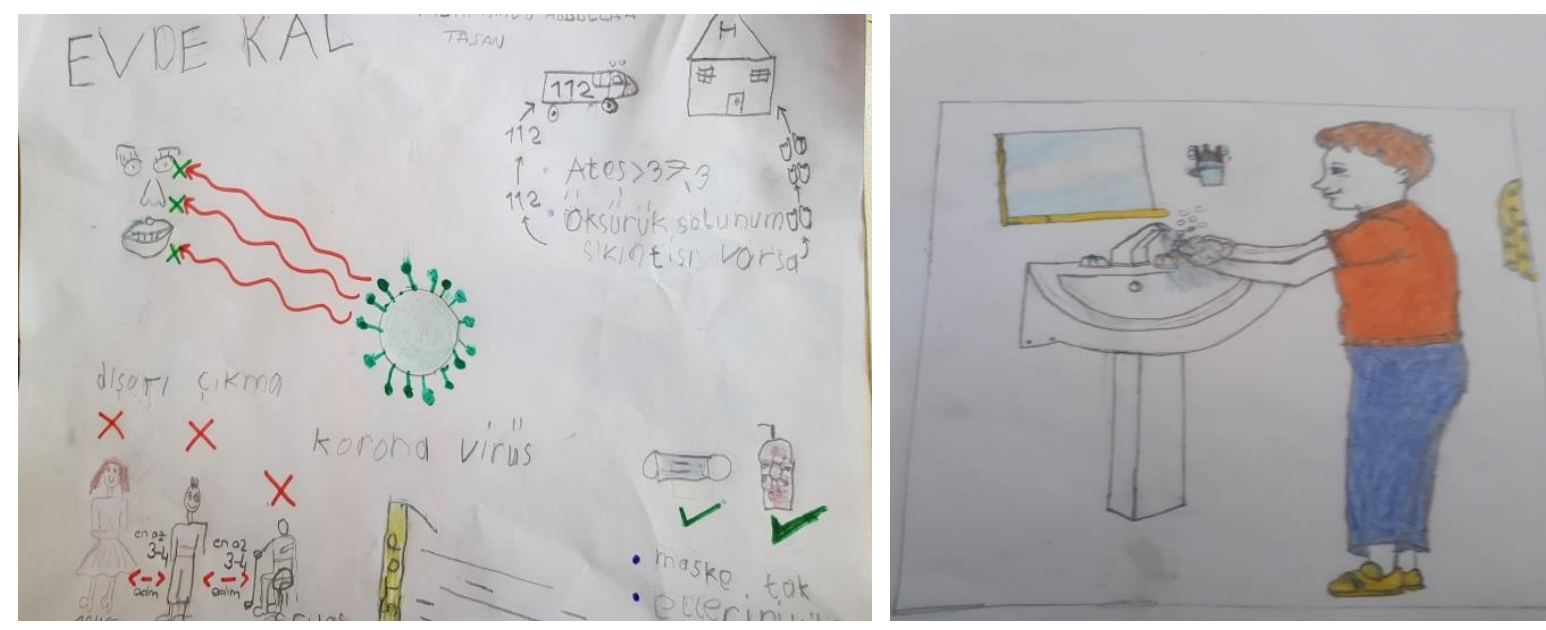

During the interviews, the children stated the importance of hand cleaning and that the hands should not touch the mouth, nose, and face. By reflecting the same idea to their paintings, they indicated their feelings in the drawings of the mouth, nose, Coronavirus moving towards the face, and children washing hands.

When the participants' views were examined, it was revealed that they understood the importance of washing hands, wearing a mask, staying at home, maintaining social distance, and paying attention to cleanliness. It can be acknowledged that both the family and teacher's warnings and the media products in the form of notifications, news, and public spots applied by the government on TV and other communication channels are also beneficial in creating this awareness.

\subsection{Results on the sub-theme: "What are the effects of Coronavirus on our lives?"}

In the context of Coronavirus's effects on our lives, children stated that the virus caused schools to close. They revealed their longing feelings that occurred with the closing of the school. They also noted that Coronavirus caused them to receive distance education. In this context, the closure of schools and distance education categories have emerged under the subtheme of "what are the effects of Coronavirus on our life."

\subsubsection{Caused schools to close}

As a result of the schools' closure, Azra stated that she missed the school and that she was able to ask her teacher at the school and said: "I can ask my teacher a question. My teacher is also interested in everything. I love my teacher."

Similarly, Ayşe stated that she was able to ask her teacher and miss her while she was at school: "I can ask my teacher at school. I can see her."

Hamza expressed his longing feeling by saying that his teacher was better: "You are telling it slowly, and you are telling it very well, teacher. TV sometimes makes it worse."

By stating: "You are telling very well, I miss you," Ali Kerem also expressed his longing sense, that his teacher is better, and he misses her.

While explaining her longing for school, Aybike stated that she missed her friends and used the following expressions: "I see my friends alive at school and play games with them." 
Leya said that she similarly missed her friends: "I am very bored at home, teacher. I miss school and friends."

\subsubsection{Coronavirus caused distance learning}

Due to the Covid-19 pandemic, distance education was also used in primary schools, and compensation education assistance was provided through the Internet and television screens with a network called EBA (Education Information Network). Regarding the distance education system used, students expressed their positive and negative opinions.

\subsubsection{Positive opinion}

When evaluating distance education (EBA), Muhammed Ali expressed his positive side: "The teacher explains very well."

Azra said: "We see it bigger on the television. It displays better. We can change the lesson from the computer ourselves," and she evaluated the positive aspect of EBA with her words.

Stating that she had the chance to change it from the internet in a similar manner, Ayşe said: "I can repeat, I can change it."

Mehmet Akif also talked about the comfort of home education and stated his positive side: "The chairs in the school are hard, but the chairs in the house are made of cotton. Therefore, I am listening to it in a comfortable environment."

On the other hand, Mehmet Taha said that the lessons were processed faster and stated his positive side in this way by saying: "It is easier to learn faster."

While evaluating EBA, Aybike said that his favorite lesson was mathematics and stated his reason as follows: "We were working hours in that math lesson. Before the lesson, the teacher said that I would like you to buy straws and red beans. We did that event with my grandmother. It was lovely."

Expressing that her favorite lesson was mathematics in EBA, Azra said, "Our teacher is very entertaining, explains very well," reported her reason.

Saying, "Because the math lesson is more interesting to me," Rabia stated that her favorite lesson was math.

When Berra evaluated EBA, she announced that her favorite lesson was Turkish. As the rationale, she replied: "Because the teacher explains it much better."

Hazal Melek said that her favorite lesson in EBA was Turkish and stated her reason as: "Because I love that lesson."

\subsubsection{Negative opinion}

While evaluating EBA, Berra declared her negative aspects: "One day the electricity was cut off, and I could not study. And the teacher answers immediately. They should not respond quickly and let us think a little at home."

Similarly, Hamza also mentioned his negative thoughts: "The teacher sometimes explains quickly. We are about to tell the answer, but the teacher says it. They must wait a little bit." 
Hazal Melek's expressed her negative opinion about EBA as: "I love teaching more at school. I cannot ask you a question here."

Azra has likewise assessed its negative side and said: "We cannot ask the teacher questions in EBA."

Ayşe stated that she could not ask the teacher as a negative side and stated as follows: "I cannot see my teacher completely. I can't ask him a direct question."

Muhammed evaluated the negative aspect of EBA by saying: "Our eyesight may fail."

blind."

Likewise, Beren evaluated the negative side of EBA by saying: "Our eyes are near-

Rabia stated that while evaluating the EBA, the issues were not understood, and she expressed her opinion as follows: "The negative side is that I do not understand some things."

Muhammed Ali stated that he asked his parents about unclear subjects when evaluating EBA: "I ask my father, my sister, and my mother when I do not understand."

Hamza asked the class teacher about the subjects that were not understood, saying: "Whenever I do not understand, I ask you, or I ask my mother."

Beren used the following expressions, saying that he watched again on the subjects that were not understood: "When I do not understand in the lessons, I repeat it from my father's phone."

On the other hand, Berra stated that she benefited from the book on subjects that were not understood, saying: "I look at the places I do not understand from my book."

It was revealed that primary school students have various opinions about distance education. The fact that watching lessons from the internet is different, having the chance to watch the lesson at any time, and the comfort of the home environment seem attractive. For these reasons, they fancy distance education. Nevertheless, the subjects that were complained by the participants were not being able to ask the teacher questions, being helpless about the things they did not understand, and sometimes not reaching the speed of the teacher who explained the lesson.

\section{Conclusion and discussion}

This study aimed to discover the primary school students' perspectives on Coronavirus and its effects. In the study, it was concluded that 1st grade primary school students define Coronavirus as a disease. Still, it has been revealed that they see Coronavirus as a global epidemic surrounding the world.

In the study, it was assumed that 1st grade primary school students have the consciousness that Coronavirus has tremendous and adverse effects on human life and threatens health. This information, which the children have, coincides with the information expressed by Lamis et al. (2020) that the Coronavirus is a rapidly spreading fatal disease. And that the virus is threatening health by infecting not only vulnerable people (children, older people, healthcare workers).

In this study, it was concluded that $1^{\text {st }}$ grade primary school students gained awareness about proper handwashing as a means of protection from Coronavirus. In the study conducted by Dominika et al. (2020), it was concluded that all hand hygiene behaviors were better during the Coronavirus secretion compared to the previous one. 
It was concluded that 1st-grade primary school students who participated in the study gained awareness about the use of masks and gloves as a method of Coronavirus protection. Along with these, wearing mandatory masks in public places and applying a home-stay policy for the entire city, the confirmed case rates in COVID-19 in Wuhan have been reduced, and the epidemic has been taken under control. Clean gloves should be worn and cover the wrist well and removed immediately after use. Surgical disposable masks can also be used, which are somewhat protective and useful, mainly as they prevent close contact with droplets (Cirrincione et al., 2020).

In this study, 1st-grade primary school students, by adopting the principle of social distance, think that life in the home is sheltered. It is essential to stay at home to prevent Coronavirus transmission. When the studies conducted are also examined, it has been seen that physical distance measures reduce the contact level and significantly decrease the risk of Coronavirus transmission. Three-way public health measures (restriction in intensive intracity and intercity traffic, social distance measures, house arrest, and central quarantine) proved to be significant (Pan et al., 2020; Jarvis et al., 2020).

Another result of this study is that $1^{\text {st }}$ grade primary school students possess awareness about the cleaning rules recommended by the authorities and that the hand should not be put in the mouth, nose, and eyes. This result suggests that the World Health Organization's (WHO, 2020) warning of "avoid touching the eyes, nose and mouth" about protecting ourselves and others from the COVID-19 outbreak is effective on children. However, this result is in contradiction with the conclusion that, in Gray et al. (2020) study, school-age children, who are defined as silent donors, are not adequately communicated at the point of health education and that children are falling short at this point.

In this study, $1^{\text {st }}$ grade primary school students stated that the schools were closed with the Coronavirus effect. With the schools' closure, the students felt a sense of longing towards their friends and teachers and thus developed a positive attitude towards the school. In the study conducted by Boulton et al. (2011), it was concluded that students with positive peer relationships developed more positive attitudes towards the school.

It was concluded that the primary school students who participated in the study received a positive attitude in the distance education system, which was implemented with the Coronavirus's effect in terms of greater comfort at home and fun lessons.

In this study, it was assumed that $1^{\text {st }}$ grade primary school students were unable to ask the teacher in distance education. They experienced disruptions in education due to the teacher's narrative speed and access to technology and that this situation was unfavorable. In this context, in a study conducted by Fox (2004), it was similarly revealed that students in the SARS epidemic had difficulties completing and implementing online learning activities in a non-classroom environment. Furthermore, Thomas and Rogers (2020) concluded that when students continue working at home without going to school, the differences in educational progress caused by inequalities can increase.

made:

In light of the conclusions reached in this research, the following suggestions can be

- In this study, it was concluded that $1^{\text {st }}$ grade primary school students create awareness against Coronavirus and prevention methods. In the subsequent researches, reviews can be conducted to determine the opinions of students studying at different grade levels.

- As it has a Coronavirus pandemic, it has affected social life all over the world. In this context, to determine the effects of Coronavirus on children's lives, studies can be conducted with teachers and parents, and the sample group can be diversified. 
- Qualitative study method was used in this research. In other analyses, quantitative or mixed-method studies can be designed.

\section{Acknowledgements}

This research did not receive any specific grant from funding agencies in the public commercial, or not-for-profit sectors.

The authors declare no competing interests.

\section{References}

Akbaba, M., Kurt, B., \& Nazlıcan, E. (2014). Yeni Coronavirus salgını [Novel Coronavirus pandemic]. Turk $J$ Public Health, 12(3), 217-227.

An P., Li L., Chaolong W., Huan G., Xingjie H., Qi W., Jiao H., Na H., Hongjie Y., Xihong L., Sheng W., \& Tangchun W. (2020). Association of public health interventions with the epidemiology of the COVID-19 outbreak in Wuhan, China. JAMA, 323(19), 1915-1923.

Arthur, J., Waring, M. R., Coe, R., \& Hedges, L.V. (2012). Research methods \& methodologies in education. SAGE Publication.

Ayres, L. (2008). Semı-structured interview. In L. M. Given (Ed.). The Sage of Encyclopedia of Qualitative Research Methods (pp. 810-811). ABD: SAGE Publication.

Berg, B. L., \& Lune, H. (2015). Sosyal Bilimlerde Nitel Araştırma Yöntemleri (8. b.) [Qualitative research methods in social sciences] (H. Aydın, Dü., \& Z. E. Özcan, trans.). Konya: Eğitim Yayınevi.

Sen-Crowe, B., McKenney, M., \& Elkbuli, A. (2020). Social distancing during the COVID-19 pandemic: Staying home save lives. American Journal of Emergency Medicine, 38, 1515-1539.

Boulton, M. J., Don, J., \& Boulton, L. (2011). Predicting children's liking of school from their peer relationships. Social Psychology of Education, 14, 489-501.

Burdina, G. M., Krapotkina, I. E., \& Nasyrova, L. G. (2019). Distance learning in elementary school classrooms: An emerging, framework for contemporary practice. International Journal of Instruction, 12(1), 1-16.

Chang, G. C. \& Yano, S. (2020 Nisan). How are countries addressing the Covid-19 challenges in education? A snapshot of policy measure. Retrived from:

https://gemreportunesco.wordpress.com/2020/03/24/how-are-countries-addressing-thecovid-19-challenges-in-education-a-snapshot-of-policy-measures/.

Cirrincione, L., Plescia F., Ledda C., Rapisarda V., Martorana D., Moldovan R. E., Theodoridou, K., \& Cannizzaro, E. (2020). COVID-19 Pandemic: Prevention and protection measures to be adopted at the workplace. Sustainability, 12(3603), 1-18.

Creswell, J. W. (2015). Nitel araştırma yöntemleri - Beş yaklaşıma göre nitel araştırma ve araştırma deseni [Qualitative research methods - Qualitative research and research design according to five approaches] (Mesut Bütün; Selçuk Beşir Demir, trans., Ed.). Ankara: Siyasal Kitabevi.

Çaykuş, E. T., \& Mutlu Çaykuş, T. (2020). COVID-19 pandemi sürecinde çocukların psikolojik dayanıklılığını güçlendirme yolları: Ailelere, öğretmenlere ve ruh sağlığı uzmanlarına öneriler [Ways to strengthen children's resilience during the COVID-19 pandemic: Recommendations to families, teachers and mental health professionals]. Avrasya Sosyal ve Ekonomi Araştırmaları Dergisi (ASEAD), 5(2), 91-113. 
Dominika, G., Dominika, S., \& Dominika, G. (2020). Population-based study of the influence of the COVID19 pandemic on hand hygiene behaviors-Polish adolescents' COVID-19 experience (PLACE19) study. Sustainability, 12(12), 1-17.

Fox, R. (2004). SARS epidemic: Teachers' experiences using ICTs. In Beyond the comfort zone: Proceedings of the 21st ASCILITE Conference, 5-8 December 2004, pp. 319-327.

Fowler, J. H., Hill, S. J., Levin, R., \& Obradovich, N. (2020). The effect of stay-at-home orders on COVID19 cases and fatalities in the United States. Cornell University Library. Retrieved from http://arxiv.org/abs/2004.06098.

Fraenkel, J., Wallen, N., \& Hyun, H. (2012). How to design and evaluate research in education (8 ${ }^{\text {th }}$ Ed.). NY: McGraw-Hill.

Gao, S., Rao, J., Kang, Y., Liang, Y., Kruse, J., Doepfer, D., Sethi, A. K., Reyes, J. F. M., Patz, J., \& Yandell, B. S. (2020). Mobile phone location data reveal the effect and geographic variation of social distancing on the spread of the COVID-19 epidemic. Cornell University Library. Retrieved from https://arxiv.org/abs/2004.11430.

Gray, D. J., Kurscheid, J., Mationg, M. L., Williams, G. M., Gordon, C., Kelly, M., Wangdi, K., \& McManus, D. P. (2020). Health-education to prevent COVID-19 in schoolchildren: A call to action. Infectious Diseases of Poverty, 81(9), 1-3.

Gulati, A., Pomeranz, C., Qamar, Z., Thomas, S., Frisch, D., George, G., Summer, R., DeSimone, J., \& Sundaram, B. (2020). A comprehensive review of manifestations of novel Coronaviruses in the context of deadly COVID-19 global pandemic. The American Journal of the Medical Science, 36o(1), 5-34.

Güner, R., Hasanoğlu, İ., \& Aktaş, F. (2020). COVID-19: Prevention and control measures in community. Turkish Journal of Medical Sciences, 50, 571-577.

Jarvis, C. I., Kevin V. Z., Gimma, A., Kiesha, P., Klepac, P., Rubin, G. J., \& Edmunds, W. J. (2020). Quantifying the impact of physical distance measures on the transmission of COVID-19 in the $\mathrm{UK}$, BMC Medicine, 18, 1-10.

Julien, H. (2008). Content Analysis. In L. M. Given (Ed.), The Sage of Encyclopedia of Qualitative Research Methods (pp. 120-121). ABD: SAGE Publication.

Lamis, M. F. E., Khalid, Z., Elwakee, \& Ahmed, M. E. (2020). COVID-19 from mysterious enemy to an environmental detection process: a critical review. Innovative Infrastructure Solutions, 84(5), 1-13.

Lee, M., Zhao, J., Sun, Q., Pan, Y., Zhou, W., Xiong, C., \& Zhang, L. (2020). Human mobility trends during the COVID-19 pandemic in the United States. Cornell University Library. Retrieved from https://arxiv.org/abs/2005.01215.

Malik, Y. A. (2020). Properties of Coronavirus and SARS-CoV-2. Malaysian J Pathol, 42(1), 3-11.

Merriam, S. B. (2013). Nitel araştirma-desen ve uygulama için bir rehber [A guide to qualitative researchdesign and practice] (S. Turan, trans.) Ankara: Nobel Akademik Yayıncılık.

Mertens, D. M. (2009). Research and evaluation in education and psychology: Integrating diversity with quantitative, qualitative, and mixed methods ( $3^{\text {rd }}$ ed.). ABD: Sage Publications.

Mıles, M. B., \& Hubermann, A. M. (1994). Qualitative data analysis. Thousand Oaks, CA: Sage Publications.

Palys, T. (2008). Purposive sampling. In L. M. Given (Ed.). The Sage of Encyclopedia of Qualitative Research Methods (pp. 697-698). ABD: SAGE Publication.

Pior, L. F. (2008). Document Analysis. L.M. Given (Ed.). The Sage of Encyclopedia of Qualitative Research Methods (pp. 230-231). ABD: SAGE Publication.

Sağlık Bakanlığı (Ministry of Health) (2020). Retrieved from https://covid19bilgi.saglik.gov.tr/tr/covid-19yeni-koronavirus-hastaligi-nedir.html. 
Shoor, P., Kaur, G. P., \& Chauhan, A. (2020). Atmospheric conditions affecting the transmission of Covid19 virus. Preprints. http://doi.org/10.20944/preprints202005.0467.v1

Thomas, M. S. C., \& Rogers, C. (2020). Education, the science of learning, and the COVID-19 crisis, Prospects. Retrieved from https://doi.org/10.1007/s11125-020-09468-Z

Tull, M. T., Edmonds, K. A., Scamaldo, K. M., Richmond, J. R., Rose, J. P., \& Grats, K. L. (2020). Psychological outcomes associated with stay-at-home orders and the perceived impact of COVID-19 on daily life. Psychiatry Research, 289, 1-6.

UNICEF (2020). Interim guidance for COVID-19 PREVENTION AND CONTROL IN SCHOOLS. Retrieved from

https://www.unicef.org/media/66216/file/Key\%20Messages\%20and\%20Actions\%20for\%20 COVID19\%20Prevention\%20and\%20Control\%20in\%20Schools March\%202020.pdf.

Venigalla, A. S. M., Dheeraj, V., \& Chimalakonda, S. (2020). Survive Covıd-19 - A game for improving awareness of social distancing and health measures for Covid-19 pandemic. Cornell University Library. Retrieved from http://arxiv.org/abs/2004.09759.

World Health Organization (WHO) (2020). Protecting yourself and others from the spread COVID-19. Retrieved from https://www.who.int/emergencies/diseases/novel-coronavirus-2019/advicefor-public.

Wilder, A. S., \& Freedman, D. O. (2020). Isolation, quarantine, social distancing and community containment: Pivotal role for old-style public health measures in the novel Coronavirus (2019nCoV) outbreak. Journal of Travel Medicine, 1-4. https://doi.org/10.1093/jtm/taaa020.

Xiong, C., Hu, S., Yang, M., Younes, H. N., Luo, W., Ghader, S., \& Zhang, L. (2020). Data-driven modeling reveals the impact of stay-at-home orders on human mobility during the COVID-19 pandemic in the U.S. Cornell University Library. Retrieved from https://arxiv.org/abs/2005.00667.

Yıldırım, A., \& Şimşek, H. (2013). Sosyal bilimlerde nitel araştirma yöntemleri [Qualitative research methods in social sciences]. Ankara: Seçkin Yayıncılık.

Yıldız, A., Çetinkaya, M., Leventoğlu, S., \& Şenköylü, A. (2020). Recommendations for surgical interventions during COVID-19 pandemic. GMJ, 31, 283-286. 
N. Duban \& F. Gül - Coronavirus in the Children's World: Discourses and Drawings

C O A $\mathbf{s}$ 